Ambiente \& Água - An Interdisciplinary Journal of Applied Science
ISSN 1980-993X - doi:10.4136/1980-993X
www.ambi-agua.net
E-mail: ambi.agua@gmail.com

\title{
Decolorization of textile azo dye Reactive Red 239 by the novel strain Shewanella xiamenensis G5-03 isolated from contaminated soil
}

\author{
ARTICLES doi:10.4136/ambi-agua.2446
}

Received: 16 Jul. 2019; Accepted: 20 Oct. 2019

\begin{abstract}
Aline Silva Cossolin ${ }^{1}$; Hélen Cristina Oliveira dos Reis ${ }^{2}$;
Ketinny Camargo de Castro' ${ }^{2}$; Bruna Assis Paim dos Santos ${ }^{3}$;

Matheus Zimermann Marques ${ }^{4}{ }^{-}$; Carlos Adriano Parizotto ${ }^{4}{ }^{i}$;

Evandro Luiz Dall’Oglio ${ }^{4}$; Leonardo Gomes de Vasconcelos ${ }^{4}$; Eduardo Beraldo de Morais ${ }^{5 *(10)}$
\end{abstract}

${ }^{1}$ Departamento de Engenharia Hidráulica e Saneamento (SHS), Escola de Engenharia de São Carlos (EESC/USP), Avenida Trabalhador São Carlense, n 400, CEP: 13566-590, São Carlos, SP, Brazil. E-mail: aline.cossolin@gmail.com

${ }^{2}$ Programa de Pós-Graduação em Ciência e Tecnologia Ambiental (PPGCTA). Universidade Tecnológica Federal do Paraná (UTFPR), Rua Deputado Heitor Alencar Furtado, nº 5000, CEP: 81280-340, Curitiba, PR, Brazil. E-mail: helenreis08@gmail.com,ketinnycamargo@gmail.com

${ }^{3}$ Programa de Pós-Graduação em Recursos Hídricos (PPGRH). Faculdade de Arquitetura, Engenharia e Tecnologia (FAET). Universidade Federal de Mato Grosso (UFMT), Avenida Fernando Corrêa da Costa, n 2367, CEP: 78060-900, Cuiabá, MT, Brazil. E-mail: bruna.santos_assis@ hotmail.com

${ }^{4}$ Programa de Pós-Graduação em Química (PPGQ). Instituto de Ciências Exatas e da Terra (ICET). Universidade Federal de Mato Grosso (UFMT), Avenida Fernando Corrêa da Costa, $\mathrm{n}^{\circ} 2367$,

CEP: 78060-900, Cuiabá, MT, Brazil. E-mail: m.zimermannmarques@gmail.com, caparizotto@gmail.com,dalloglio.evandro@gmail.com, vasconceloslg@ufmt.br

${ }^{5}$ Faculdade de Arquitetura, Engenharia e Tecnologia (FAET). Departamento de Engenharia Sanitária e Ambiental (DESA). Universidade Federal de Mato Grosso (UFMT), Avenida Fernando Correia da Costa, n² 2367, CEP: 78065-700, Cuiabá, MT, Brazil

*Corresponding author. E-mail: beraldo_morais@yahoo.com.br

\begin{abstract}
Shewanella xiamenensis G5-03 isolated from contaminated landfill soil efficiently decolorized five textile azo dyes under static conditions. One of them, Reactive Red 239 (RR239), was completely decolorized at a $\mathrm{pH}$ range of 7 to 11 (at $35^{\circ} \mathrm{C}$ ) within $3-6 \mathrm{~h}$. The bacterium was also efficiently decolorized RR239 in a wide temperature range of $25-40^{\circ} \mathrm{C}$ (at pH 8). The kinetics of RR239 decolorization by G5-03 fitted to the Michaelis-Menten Model $\left(K_{m}=443.3 \mathrm{mg} \mathrm{L}^{-1}, V_{\max }=166.7 \mathrm{mg} \mathrm{L}^{-1} \mathrm{~h}^{-1}\right)$. The decolorization of RR239 was monitored by UV-Vis and FTIR spectroscopy, which showed significant changes in peak positions when compared to the dye spectrum. Overall, the ability of S. xiamenensis G5-03 to decolorize textile azo dyes in a wide range of temperatures and $\mathrm{pH}$ (neutral-alkaline) indicate that this strain is a potential candidate for treating dye-containing effluent.
\end{abstract}

Keywords: bacterium, biodegradation, FTIR, kinetic study, Reactive Red 239.

This is an Open Access article distributed under the terms of the Creative Commons Attribution License, which permits unrestricted use, distribution, and reproduction in any medium, provided the original work is properly cited. 


\section{Descoloração do corante têxtil azo Reactive Red 239 por uma nova linhagem Shewanella xiamenensis G5-03 isolada de solo contaminado}

\section{RESUMO}

Shewanella xiamenensis G5-03 isolada de solo contaminado de aterro sanitário foi eficiente em descolorir cinco corantes têxteis azos em condições estáticas. Um deles, Reactive Red 239 (RR239), foi completamente descolorido na faixa de $\mathrm{pH}$ de 7 a 11 (a $35^{\circ} \mathrm{C}$ ) dentro de 3-6 h. A bactéria também foi eficiente em descolorir RR239 em uma ampla faixa de temperatura de $25-40^{\circ} \mathrm{C}$ (em pH 8). A cinética de descoloração do RR239 pela G5-03 se ajustou ao modelo de Michaelis-Menten $\left(K_{m}=443,3 \mathrm{mg} \mathrm{L}^{-1}, V_{\max }=166,7 \mathrm{mg} \mathrm{L}^{-1} \mathrm{~h}^{-1}\right)$. A descoloração do RR239 foi monitorada por espectroscopia UV-Vis e FTIR, que mostrou mudanças significativas nas posições dos picos quando comparadas ao espectro do corante. No geral, a capacidade de $S$. xiamenensis G5-03 para descolorir os corantes têxteis azo em uma ampla faixa de temperatura e pH (neutro-alcalino) indica que esta cepa é uma candidata em potencial para o tratamento de efluente contendo corante.

Palavras-chave: bactéria, biodegradação, estudo cinético, FTIR, Reactive Red 239.

\section{INTRODUCTION}

Textile dyes are recalcitrant compounds, and most of them and some of their metabolites are toxic, mutagenic, and carcinogenic. During the dyeing process, around $15 \%$ of the dyes are lost in wastewater (Vikrant et al., 2018), and this is the cause of serious environmental and health concerns. Textile dyes in aqueous ecosystems may affect aesthetic qualities, reduce light penetration, which is essential for photosynthesis, and make oxygen transference into the water difficult, causing acute toxic effects on aquatic organisms (Saratale et al., 2011).

Various conventional physico-chemical wastewater treatment processes including flocculation, chemical coagulation, precipitation, ozonation, photocatalysis, color irradiation, and adsorption have been applied for textile effluent decolorization. These techniques, however, have limitations such as high cost, the formation of large quantities of sludge containing the dyes and their metabolites and intensive energy requirements (Castro et al., 2017). On the other hand, bioremediation is considered an efficient and economical technique widely studied in recent years to treat several kinds of industrial effluents. This technology is based on biological processes in which microorganisms can degrade and even mineralize hazardous compounds, including textile dyes, with low environmental impact, costs, and energy requirements (Saratale et al., 2011).

Azo dyes are characterized by one or more chromophore (azo) group $(-\mathrm{N}=\mathrm{N}-)$ in their chemical structures and constitute the largest group used in textile dyestuffs, representing about $60-70 \%$ by weight. According to the number of chromophore groups in the molecule, azo dyes are classified as monoazo, diazo or triazo, and are available in six application categories: acid, basic, disperse, direct, azoic, and pigments (Meng et al., 2014). Studies have shown that several bacterial genera can decolorize azo dyes: Alcaligenes (Shah et al., 2012), Pseudomonas (Hussain et al., 2013), Enterobacter (Holkar et al. 2014), Aeromonas, Exiguobacterium (Hsueh et al., 2016), and Halomonas (Guadie et al., 2018). Despite the diversity of bacteria that can decolorize azo dyes, the mechanism of decolorization is similar for all of them and involves the reductive cleavage of the azo bond by azoreductases in anaerobic conditions. Posteriorly, the end products of this reaction are degraded by hydrolases and oxygenases produced by bacteria in aerobic conditions (Vikrant et al., 2018).

In this study, textile azo dyes were decolorized by a novel strain, Shewanella xiamenensis G5-03, isolated from contaminated landfill soil. Considering that several environmental 
conditions influence the dye-decolorization process, variables including $\mathrm{pH}$, temperature, dye concentration, aerobic, and microaerophilic incubation were studied to achieve maximum dye degradation. The confirmation of dye degradation was carried out using UV visible spectroscopy and Fourier transform infrared spectroscopy (FTIR) analysis.

\section{MATERIALS AND METHODS}

\subsection{Dyes, chemicals and culture media}

Textile azo dyes used, i.e., Reactive Red 239 (RR239), Reactive Yellow 176 (RY176), Reactive Black B (RBB), Direct Blue 85 (DB85), and Direct Orange 39 (DO39) were obtained from Têxtil São João (São João da Boa Vista, SP, Brazil), and used as received without further purification. Sterile stock solutions of the dyes were prepared by dissolving the powdered dyestuff in distilled water and sterilized by filtration (Millipore cellulose filters $\varnothing 0.22 \mu \mathrm{m}$ ), and the other concentrations were obtained by diluting these stock dye solutions. All other chemicals used in this study were of analytical grade.

Tryptic soy broth (TSB) was purchased from Himedia Labs and consisted of $\left(\mathrm{g} \mathrm{L}^{-1}\right)$ : pancreatic digest of casein 17.0, papaic digest of soybean meal 3.0, sodium chloride 5.0, dextrose 2.5, dipotassium hydrogen phosphate $2.5, \mathrm{pH} 7.3 \pm 0.2$. Agar was added in TSB (1.5\% w/v) to prepare tryptic soy agar (TSA) used in the stock culture of the bacterial strain. Rich mineral medium (MMR) used in all decolorization experiments contained $\left(\mathrm{g} \mathrm{L}^{-1}\right): \mathrm{K}_{2} \mathrm{HPO}_{4} 1.6$, $\mathrm{KH}_{2} \mathrm{PO}_{4} 0.2,\left(\mathrm{NH}_{4}\right)_{2} \mathrm{SO}_{4} 1.0, \mathrm{MgSO}_{4} .7 \mathrm{H}_{2} \mathrm{O}$ 0.2, $\mathrm{FeSO}_{4} .7 \mathrm{H}_{2} \mathrm{O} 0.01, \mathrm{NaCl} 0.1, \mathrm{CaCl}_{2} . \mathrm{H}_{2} \mathrm{O} 0.02$, glucose 3.0 and yeast extract 1.0.

\subsection{Decolorizing bacterial strain}

The stock cultures were maintained by periodic subculture on TSA slants at $4^{\circ} \mathrm{C}$. This bacterial strain was isolated from contaminated landfill soil in Cuiabá, Brazil. The identification of the strain was based on the analysis of 16S ribosomal RNA (rRNA) gene. After the cells were cultured overnight in TSB, the genomic DNA was extracted using a Bacterial Genomic Miniprep Kit from Sigma Aldrich. The 16S rRNA gene fragment of the strain was then amplified by PCR amplification using forward primer $27 \mathrm{f}$ (5'AGAGTTTGATCCTGGCTCAG-3') and reverse primer 1492r (5'GGTTACCTTGTTACGACTT-3'). The 16S rRNA PCR product was purified using GFX ${ }^{\mathrm{TM}}$ PCR Purification Kit (GE Healthcare) and sequenced by GenOne (Rio de Janeiro, Brazil) using the Sanger method. The 16S rRNA sequence of the decolorizing bacterial strain was compared with the 16S rRNA sequence data from the reference and type strains available in the public database GenBank using BLASTn (https://blast.ncbi.nlm.nih.gov/Blast.cgi).

\subsection{Inoculum preparation}

To inoculum preparation used in decolorization experiments, a loopful of the decolorizing bacterial strain grown on TSA plate $\left(24 \mathrm{~h}, 35^{\circ} \mathrm{C}\right)$, was inoculated in an Erlenmeyer flask containing $100 \mathrm{~mL}$ MMR ( $\mathrm{pH} 7.0$ ). The flask was incubated at $35^{\circ} \mathrm{C}$ in a shaking incubator $(150 \mathrm{rpm})$ until the exponential phase of bacterial growth was reached. A microbial culture with an optical density of 1.0 (at $600 \mathrm{~nm}$ ) was used as inoculum (5\% v/v).

\subsection{Decolorization studies}

Decolorization experiments were carried out in an Erlenmeyer flask $(250 \mathrm{~mL})$ containing $100 \mathrm{~mL}$ MMR supplemented with dye $\left(50 \mathrm{mg} \mathrm{L}^{-1}\right)$. Five azo dyes were studied individually (RR239, RRB, RY176, DB85, and DO39). The flasks were incubated at $35^{\circ} \mathrm{C}$ under static condition. Dye concentration was measured following the colorimetric procedure of using curves prepared at $\lambda_{\max }$ of $542 \mathrm{~nm}$ (RR239), $597 \mathrm{~nm}$ (RRB), $418 \mathrm{~nm}$ (RY176), $590 \mathrm{~nm}$ (DB85), and $420 \mathrm{~nm}$ (DO39), using UV-Vis spectrophotometer Hach DR6000. To avoid biomass 
interference during dye concentration, determination cells were removed by centrifugation $(6,000 \mathrm{xg}, 15 \mathrm{~min})$. All decolorization experiments were performed in triplicate. Uninoculated controls were always included to estimate the abiotic decolorization. The percentage of decolorization was calculated according to Equation 1:

Decolorization $(\%)=\frac{C_{(0 h)}-C_{(t)}}{C_{(0 h)}} \times 100$

Where $C_{(0 \mathrm{~h})}$ is the initial concentration of dye, and $C_{(\mathrm{t})}$ is the concentration of dye at reaction time $\mathrm{t}$ (hour).

\subsection{Analysis of color removal in MMR containing a mixture of dyes}

Decolorization of a mixture of all dyes, each at a concentration of $30 \mathrm{mg} \mathrm{L}^{-1}$, was evaluated in a MMR. The mixture of dyes did not have a well-defined peak at the visible absorption spectra. Therefore, the actual color level was measured using the American Dye Manufacturers Institute (ADMI) weighted-ordinate spectrophotometric method (method 2120F from Standard Methods for the Examination Water and Wastewater) (APHA et al., 2012). The percentage of decolorization was calculated according to Equation 2:

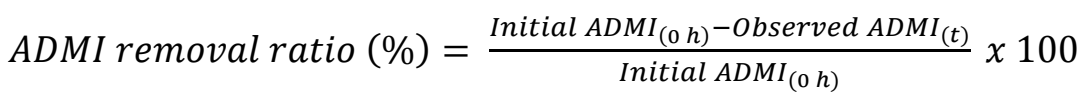

Where $\operatorname{ADMI}_{(0 \mathrm{~h})}$ and $\mathrm{ADMI}_{(\mathrm{t})}$ are the initial $\mathrm{ADMI}$ value $($ at $0 \mathrm{~h})$ and the $\mathrm{ADMI}$ value after a particular reaction time $(\mathrm{t})$, respectively.

\subsection{Effects of different parameters on RR239 decolorization}

RR239 was used to study the effects of different environmental parameters on decolorization since it was required less time for its complete decolorization. Temperature (25$\left.45^{\circ} \mathrm{C}\right), \mathrm{pH}(4.0-12.0)$, static/agitated incubation, and dye concentration (50-800 $\mathrm{mg} \mathrm{L}^{-1}$ ) were evaluated. Repetitive decolorization capacity of the decolorizing bacterial strain by addition of RR239 (50 $\left.\mathrm{mg} \mathrm{L}^{-1}\right)$ at medium without supplementing any additional nutrient was also studied. Since dye decolorization may take place by biosorption or biodegradation, dead biomass was obtained by samples autoclaving $\left(121^{\circ} \mathrm{C}, 20 \mathrm{~min}\right)$ and was used for estimation of biosorption.

\subsection{Measurement of biomass}

The biomass was determined by measuring the optical density (OD) at a wavelength of $600 \mathrm{~nm}$ during decolorization (Holkar et al., 2014):

$\mathrm{OD}_{600}=\mathrm{OD}_{\text {sample }}-\mathrm{OD}_{\text {supernatant }}$

\subsection{Analysis of metabolites obtained after RR239 decolorization}

FTIR analysis of metabolites obtained after RR239 decolorization was done on a Shimadzu IRAffinity-1 spectrophotometer (Model: IRAffinity-1; Catalogue Number: 206-73500-38; Serial Number: A21374902249S1; Brand: Shimadzu Corporation spectrophotometer). Decolorized samples were centrifuged at $10,000 \times \mathrm{g}$ for $15 \mathrm{~min}$, and the extraction of metabolites was carried out from the supernatant using an equal volume of ethyl acetate. The extracts were dried over anhydrous $\mathrm{Na}_{2} \mathrm{SO}_{4}$ and evaporated to dryness in a rotary evaporator. The samples were mixed with spectroscopically pure $\mathrm{KBr}(0.0005 \mathrm{~g}$ sample : $0.1 \mathrm{~g} \mathrm{KBr})$, pellets were fixed in a sample holder, and then analyzed. The qualitative analyses were carried out using the following parameters: Measured Mode (\% Transmittance), Apodization (Happ_Genzel), Number of Scans (200), Resolution (16), Range (400-4000 $\mathrm{cm}^{-1}$ ), Gain (1). The background obtained from $\mathrm{KBr}$ disks was automatically subtracted from the samples disks spectra. 


\section{RESULTS AND DISCUSSION}

\subsection{Identification of decolorizing bacterial strain}

The colony of the decolorizing bacterial strain was circular, flat, smooth, and reddishbrown. The bacterium was observed to be Gram-negative. Sequence analysis of the 16S rRNA gene showed that the strain had the highest similarity with the species Shewanella xiamenensis $(99.51 \%)$. The sequence of the bacterial strain was submitted to GenBank with the accession number MN005116.

\subsection{Decolorization performance of azo dyes}

The decolorization of the azo dyes RR239, RY176, RBB, DB85 and DO39 (50 mg L-1 each) by $S$. xiamenensis G5-03 was evaluated in MMR within $5 \mathrm{~h}, 35^{\circ} \mathrm{C}, \mathrm{pH} 7.0$ and static condition. The results are presented in Table 1, showing that $S$. xiamenensis G5-03 decolorized all of them, with faster decolorization rates of RR239 (complete decolorization) and DB85 (97\%). S. xiamenensis G5-03 also decolorized the MMR with the mixtures of the dyes (74\% of color removal in terms of ADMI value). After $24 \mathrm{~h}$, the color removal in terms of ADMI was $98 \%$ (data not shown), indicating that the bacterium represents a promising tool for the color removal of various azo dyes from textile dye effluent. RR239 was selected for further studies because of its complete decolorization.

Table 1. Decolorization performance of azo dyes by $S$. xiamenensis G5-03.

\begin{tabular}{lll}
\hline Dye & Chemical class & Decolorization (\%) \\
\hline RR239 & Reactive monoazo & CD \\
RY176 & Reactive monoazo & $80 \pm 1.4$ \\
RRB & Reactive diazo & $86 \pm 0.7$ \\
DO39 & Direct monoazo & $75 \pm 0.6$ \\
DB85 & Direct triazo & $97 \pm 0.6$ \\
Mixture of dyes & & $74 \pm 0.2^{* *}$ \\
\hline CD - Complete decolorization & \\
${ }^{*} 30$ mg L L $^{-1}$ each dye; ${ }^{* *}$ color removal in terms of ADMI value \\
Data are shown as mean \pm std derived from triplicates.
\end{tabular}

\subsection{Effect of $\mathrm{pH}$ and temperature on RR239 decolorization}

The effect of $\mathrm{pH}$ and temperature on the decolorization of RR239 by S. xiamenensis G503 was studied in detail, since these factors play a crucial role in the optimal physiological performance of microbial culture. S. xiamenensis G5-03 revealed effective removal of RR239 color at a wide range of $\mathrm{pH}$. The dye was completely decolorized at $\mathrm{pH} 7,8$, and 9 in 5, 3, and $4 \mathrm{~h}$, respectively, and $6 \mathrm{~h}$ were necessary to remove color at $\mathrm{pH} 10$ and 11 (Table 2). In the decolorization system without bacteria (control), the decolorization rates varied between 3.7$5.4 \%$ at $\mathrm{pH} 7-11$, and at other $\mathrm{pH}$ values, the decolorization was insignificant (data not shown). Studies have demonstrated that microorganisms have higher decolorization efficiency under neutral conditions than acidic or alkaline (Shah et al,. 2012; Hussain et al., 2013). On the other hand, it has been reported that some alkali-stable azoreductase were found with bacteria (Tan et al., 2013). Brevibacillus laterosporus exhibited the ability to decolorize Disperse Red 54 dye within the $\mathrm{pH}$ range of 7-11 (Kurade et al., 2016). Enterobacter sp. F NCIM 5545 showed significantly higher decolorization of Reactive Blue 19 at $\mathrm{pH} 10$ when compared to that at $\mathrm{pH}$ 5 and 7 (Holkar et al., 2014). The $\mathrm{pH}$ tolerance of decolorizing bacteria is important because reactive dyes bind to cotton fibers by addition or substitution mechanisms under alkaline conditions (Aksu, 2003). Thus, the ability of S. xiamenensis G5-03 to decolorize reactive dyes in alkaline $\mathrm{pH}$ make it suitable for application in biotreatment of textile industry effluent. 
When the decolorization of RR239 by S. xiamenensis G5-03 was studied at various temperatures, it was observed that the highest decolorization rate was obtained at $35^{\circ} \mathrm{C}$ (complete decolorization in $5 \mathrm{~h}$ ) (Table 2). At 25,30 , and $35^{\circ} \mathrm{C}$, high decolorization rates were also observed. When the temperature was increased to $45^{\circ} \mathrm{C}$, a marginal reduction in the decolorization activity was observed (9\%). Probably this reduction is due to the loss of cell viability and deactivation of the enzymes responsible for decolorization at such high temperature (Holkar et al., 2014). Whereas the optimal decolorization rates were observed at $\mathrm{pH} 8.0$ and $35^{\circ} \mathrm{C}$, these conditions were used in subsequent studies.

Deactivated cells of $S$. xiamenensis G5-03, reached by sterilization at $121^{\circ} \mathrm{C}$ for $20 \mathrm{~min}$, did not show any significant color removal of RR239, suggesting that the decolorization was mainly attributed to biodegradation rather than biosorption.

Table 2. Effect of $\mathrm{pH}$ and temperature on the decolorization of RR239.

\begin{tabular}{lcccccccccccc}
\hline & \multicolumn{4}{c}{$\mathrm{pH}\left(\right.$ Temperature $\left.35^{\circ} \mathrm{C}\right)$} & \multicolumn{5}{c}{ Temperature $\left({ }^{\circ} \mathrm{C}\right)(\mathrm{pH} 7.0)$} \\
\cline { 2 - 14 } & 6 & 7 & 8 & 9 & 10 & 11 & 25 & 30 & 35 & 40 & 45 \\
\hline Pecolorization (\%) & $55 \pm 1.9$ & $\mathrm{CD}$ & $\mathrm{CD}$ & $\mathrm{CD}$ & $\mathrm{CD}$ & $\mathrm{CD}$ & $88 \pm 1.3$ & $94 \pm 0.9$ & $\mathrm{CD}$ & $92 \pm 2.9$ & $9 \pm 0.7$ \\
Time for decolorization (h) & 24 & 5 & 3 & 4 & 6 & 6 & 6 & 6 & 5 & 7 & 24 \\
\hline
\end{tabular}

$\mathrm{CD}$ - Complete decolorization.

\subsection{Effect of static/agitated incubation}

The growth of $S$. xiamenensis G5-03 was higher under aerobic conditions (agitation, 100 rpm) than microaerophilic (static) conditions (Figure 1). On the other hand, the agitation had a negative impact on the RR239 removal (only $42 \%$ of dye was removed after $5 \mathrm{~h}$ ), while $96 \%$ of RR239 was removed in low oxygen. This result suggested that molecular oxygen inhibits azoreductase activities responsible for the process of the dye decolorization, although the cell growth is stimulated. This inhibition has been attributed to a predominant competition for NADH utilization by aerobic respiration, which triggers an electron transfer from NADH to oxygen to form ATP and deprive the azoreductase of obtaining electrons to decolorize azo dyes (Chang et al., 2001).

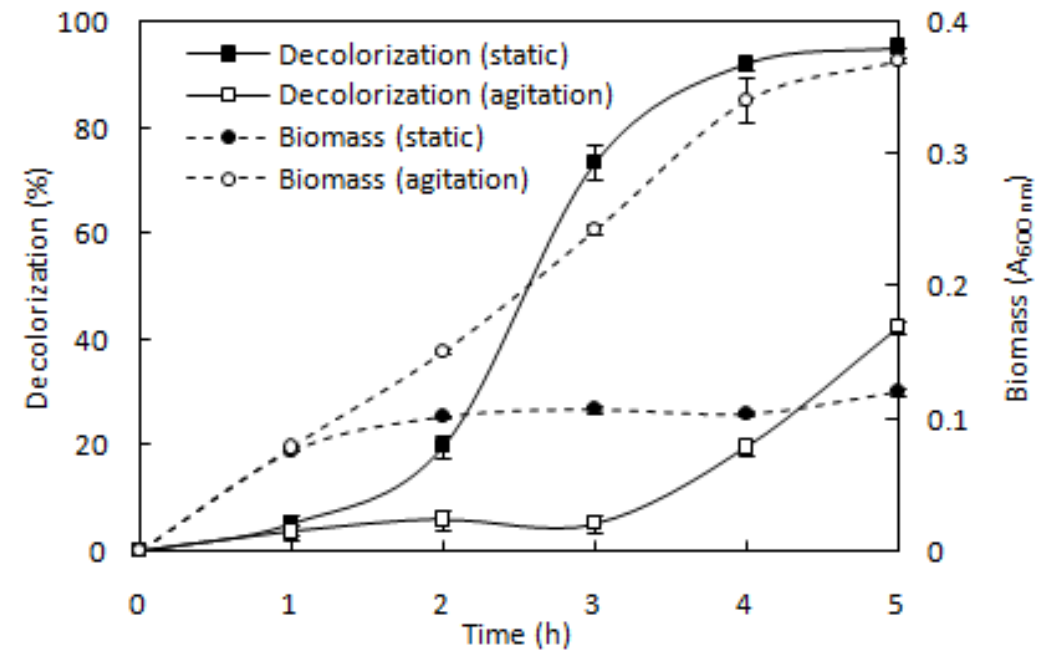

Figure 1. Effect of static and agitated incubation on RR239 decolorization.

Several studies have reported efficient dye decolorization under static/microaerophilic conditions when compared with agitation/aerobic conditions. Alcaligenes faecalis PMS-1 
completely removed Reactive Orange 13 color after $16 \mathrm{~h}$ under anoxic conditions, whereas only $35 \%$ decolorization was observed under aerobic conditions (Shah et al., 2012). Pseudomonas sp. RA20 had a better decolorizing potential of Reactive Black B under static incubation as compared to that of under shaking incubation. However, the growth of RA20 was relatively more under the shaking incubation as compared to that of static incubation (Hussain et al., 2013). Halomonas sp. strain A55 completely decolorized Reactive Red 184 only when incubated under anaerobic and anoxic conditions (Guadie et al., 2018).

\subsection{Effect of initial RR239 concentration on decolorization}

When studying the effect of increasing concentrations of RR239 on the decolorization performance exhibited by S. xiamenensis G5-03, an inverse relationship was observed. As the dye concentration increased from 50 to $800 \mathrm{mg} / \mathrm{L}$, the percentage of decolorization rate was found to decrease from $100 \%$ to $48.8 \%$ after $3 \mathrm{~h}$ (Figure 2). Reduction in the decolorization rates by $S$. xiamenensis G5-03 at higher dye concentration is related to the toxic effect of dye on the bacteria or inadequate biomass concentration for the uptake of higher concentrations of dye (Saratale et al., 2011).

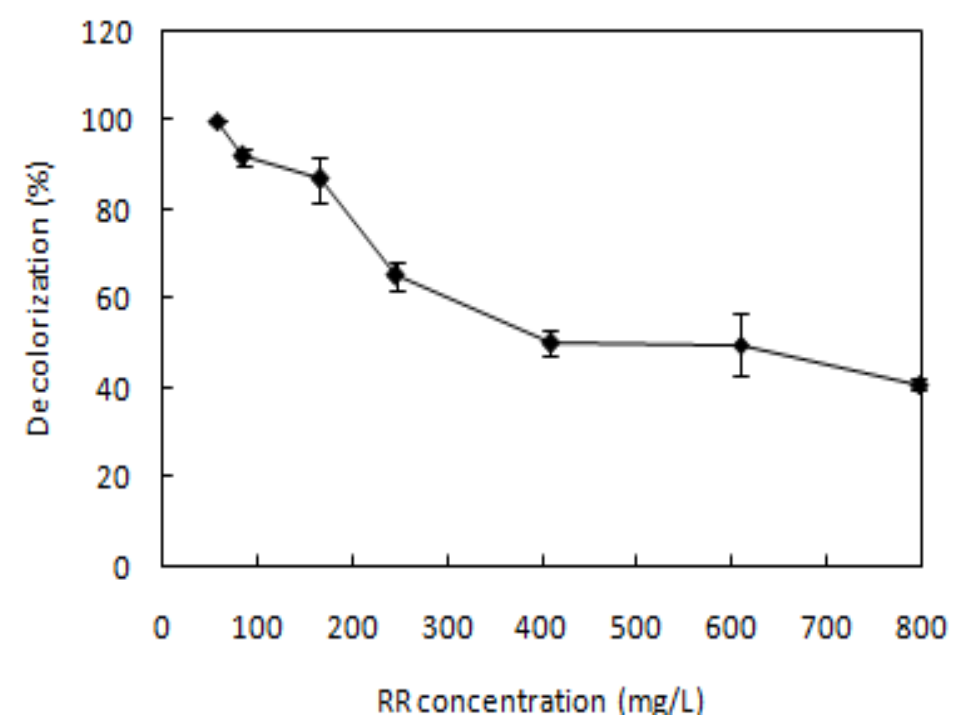

Figure 2. Effect of RR239 concentration on decolorization efficiency.

\subsection{Kinetic study of RR239 decolorization}

To determine the maximum decolorization rate of RR239, experiments with different dye concentrations (50-800 mg L $\mathrm{m}^{-1}$ ), incubated under static conditions at $35^{\circ} \mathrm{C}$, were performed. Figure 3a shows a dependence of specific decolorization rate to the concentration of RR239, and these experimental data were fitted quite well to the Michaelis-Menten model (Equation $3)$.

$$
V=\frac{V_{\max } S}{K_{m}+S}
$$

Where $V$ is the specific decolorization rate $\left(\mathrm{mg} \mathrm{L}^{-1} \mathrm{~h}^{-1}\right), V_{\max }$ is the maximum specific decolorization rate $\left(\mathrm{mg} \mathrm{L}^{-1} \mathrm{~h}^{-1}\right), S$ is the substrate concentration $\left(\mathrm{mg} \mathrm{L}^{-1}\right), K_{m}$ is the MichaelisMenten constant $\left(\mathrm{mg} \mathrm{L}^{-1}\right) . K_{m}$ is equal to the concentration of the substrate (RR239) when the reaction rate is half of the maximum velocity. To determine $V_{\max }$ and $K_{m}$, the Michaelis-Menten equation was transformed by a double-reciprocal approach as follows: $1 / V=K m /\left(V_{\max } S\right)+$ $1 / \operatorname{Vmax}$. A plot of $1 / V$ versus $1 / S$ yields a straight line (Figure $3 b$ ) with an interception of $1 / V_{\max }$ and a slope of $K_{m} / V_{\max }$. Thus, the values for $V_{\max }$ and $K_{m}$ were $166.7 \mathrm{mg} \mathrm{L}^{-1} \mathrm{~h}^{-1}$ and 443.3 $\mathrm{mg} \mathrm{L} \mathrm{L}^{-1}$, respectively. 

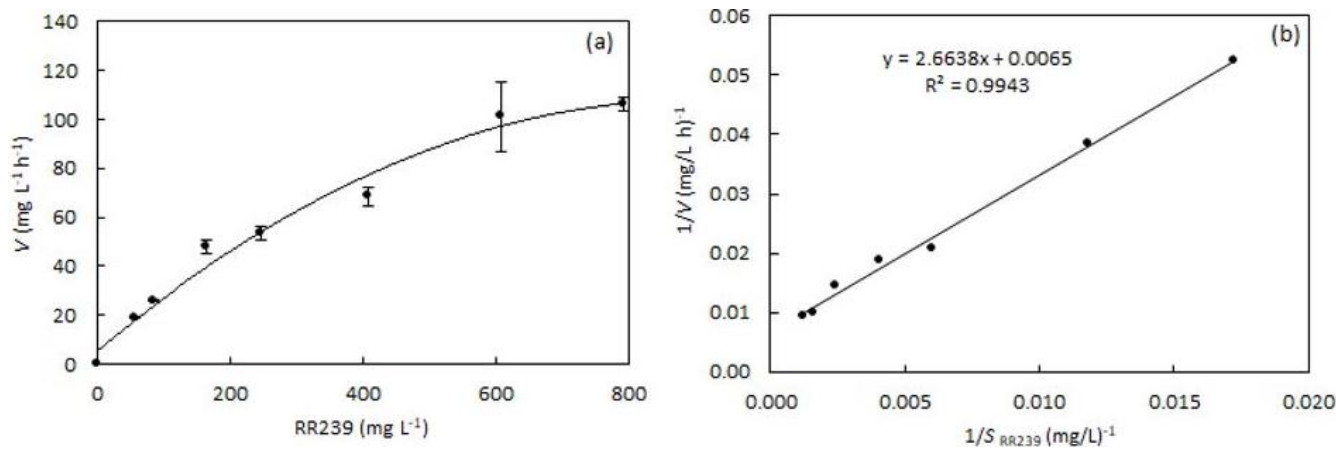

Figure 3. (a) Effect of RR239 concentration on specific decolorization rate. (b) The double reciprocal plot of initial decolorization rate against RR23 concentration.

\subsection{Decolorization of repeated additions of dye aliquots}

This study was carried out to test the ability of S. xiamenensis G5-03 to decolorize repeated addition of RR239 aliquots $\left(50 \mathrm{mg} \mathrm{L}^{-1}\right)$ after every $12 \mathrm{~h}$ at static condition. There was complete decolorization for first two dye aliquot additions, and high decolorization activity (>78\%) was observed up to the seventh cycle within $84 \mathrm{~h}$ (Figure 4). These results indicate that the G5-03 strain holds reusability and persistence in repetitive decolorization operation. Decrease in decolorization after the eighth cycle might be due to the decrease in viable cells, exhaustion of nutrients, and accumulation of toxic compounds in the medium.

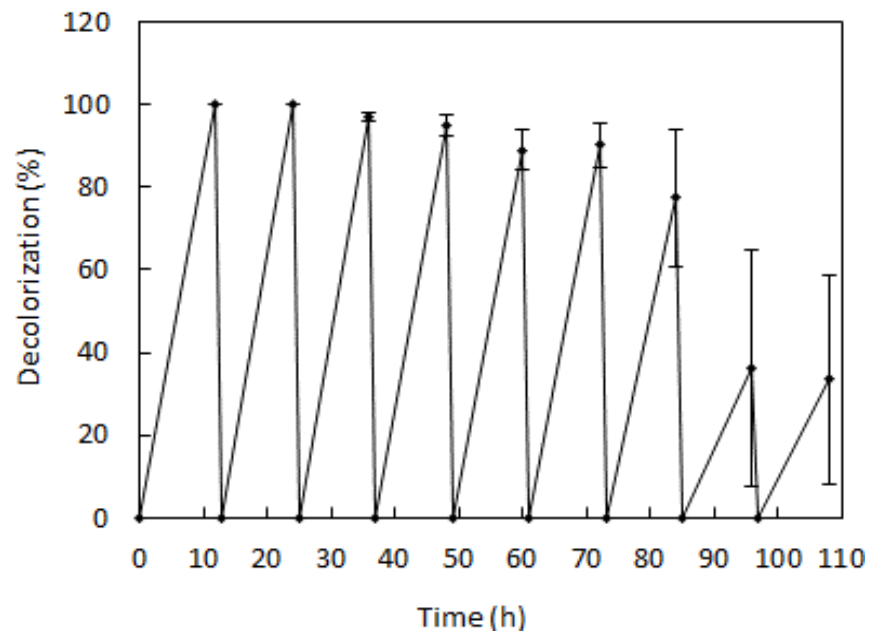

Figure 4. Repetitive decolorization capacity of the $S$. xiamenensis $\mathrm{G} 5-03$ by addition of RR239 $\left(50 \mathrm{mg} \mathrm{L}^{-1}\right)$ at medium without supplementing any additional nutrients.

\subsection{Analysis of metabolites resulting from decolorization of RR239}

Comparison of FTIR spectrum of control RR239 (before degradation) with FTIR spectrum of extracted metabolites after decolorization clearly indicated the biodegradation of the dye by S. xiamenensis G5-03 (Figure 5). The FTIR spectrum of the control RR239 (Figure 5a) showed a peak at $3456.44 \mathrm{~cm}^{-1}$ for $\mathrm{N}-\mathrm{H}$ stretching vibrations of the amino group coupled with stretching of $\mathrm{O}-\mathrm{H}$ group. Peak at $1620.21 \mathrm{~cm}^{-1}$ was attributed to the $\mathrm{N}=\mathrm{N}$ stretching vibrations of the azo bonds. The peaks at $1550.77 \mathrm{~cm}^{-1}$ for $\mathrm{C}=\mathrm{N}$ stretching and $1496.76 \mathrm{~cm}^{-1}$ for aromatic $\mathrm{C}=\mathrm{C}$ stretching supported the aromatic structure of the dye. The stretching vibration between $-\mathrm{N}-$ $\mathrm{C}=$ was reported at $1411.89 \mathrm{~cm}^{-1}$. The peaks at 1319.31 and $1141.86 \mathrm{~cm}^{-1}$ were attributed to stretching vibrations of $\mathrm{S}=\mathrm{O}$ and at $617.22 \mathrm{~cm}^{-1}$ to $\mathrm{C}-\mathrm{S}$, indicating sulfur-containing nature of the dye. Peak at $1049.28 \mathrm{~cm}^{-1}$ corresponded to stretching vibrations of the $\mathrm{C}-\mathrm{OH}$. The peaks 
between 670 and $850 \mathrm{~cm}^{-1}$ also supported the aromatic nature of the dye (Shah et al., 2012; Khan et al., 2014; Kurade et al., 2016). Absence of the peak $1620.21 \mathrm{~cm}^{-1}$ for $\mathrm{N}=\mathrm{N}$ stretching vibrations in FTIR spectrum of extracted metabolites confirming the cleavage of azo bonds, that would be an essential step for color removal. The decrease in the intensities of the peaks at the low-frequency region of spectra $\left(670-850 \mathrm{~cm}^{-1}\right)$ suggested the fission of aromatic rings. A new peak at $1651.07 \mathrm{~cm}^{-1}$ represented the formation of charged aromatic amine derivatives, whereas peak at $1303.88 \mathrm{~cm}^{-1}$ for $\mathrm{C}-\mathrm{N}$ stretching vibration support formation of aromatic primary amines. Further, new peaks around $2954-2924 \mathrm{~cm}^{-1}$ represented the C-H stretching vibrations of $\mathrm{CH}_{2}$, which could be related to aromatic ring opening. Thus, it may be concluded that $S$. xiamenensis G5-03 decolorizes RR239 due to biodegradation (Khan et al., 2014; PérezCalderón et al., 2018).

(a)

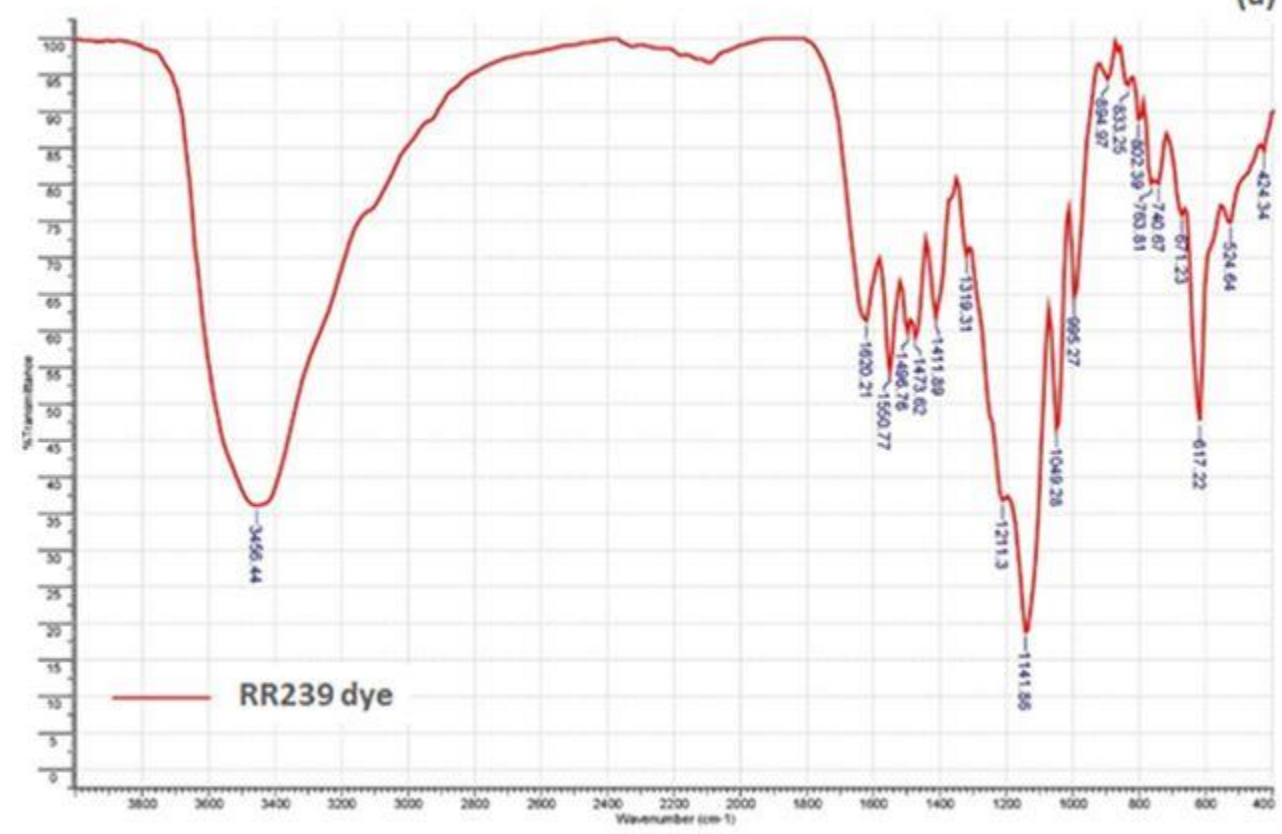

(b)

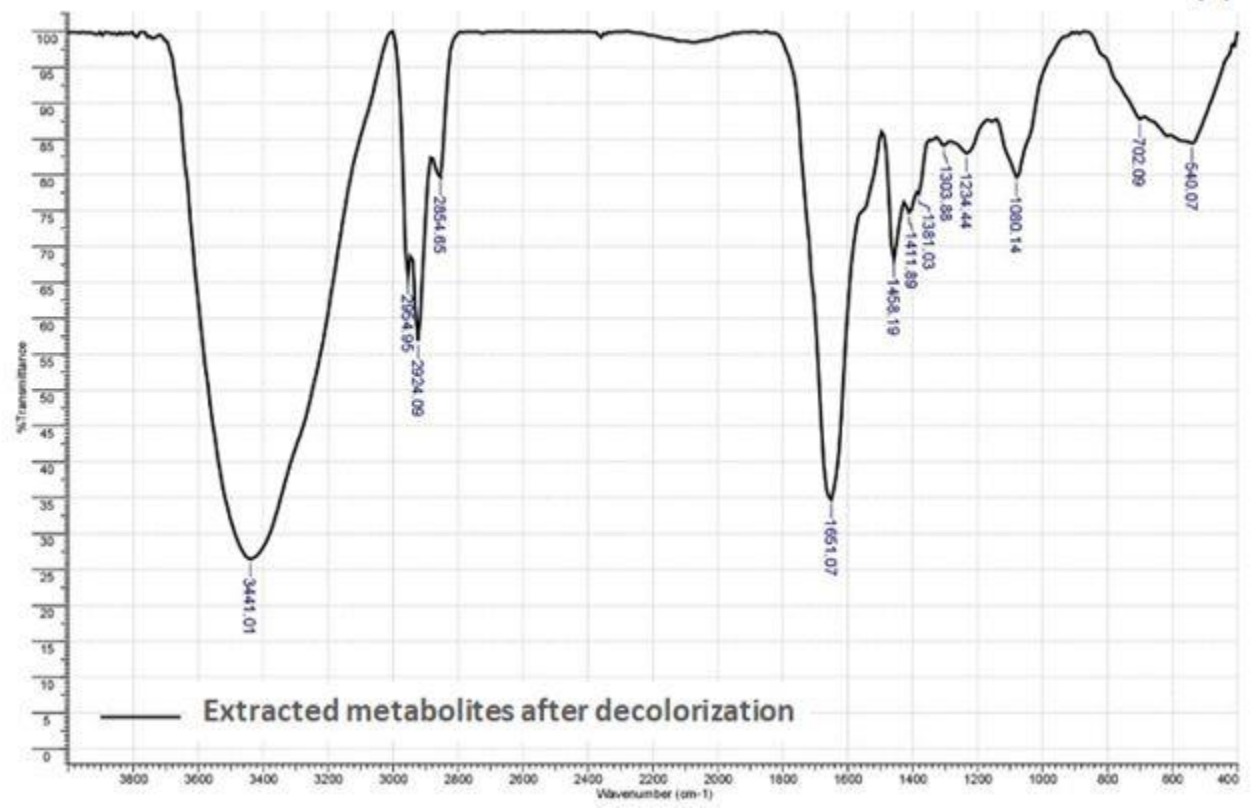

Figure 5. The FTIR spectra of RR239 dye (a) and extracted metabolites after decolorization (b). 


\section{CONCLUSION}

Textile azo dyes were decolorized by the novel strain S. xiamenensis G5-03 isolated from contaminated landfill soil, in static (microaerophilic) condition. Most notably, G5-03 effectively decolorized Reactive Red 239 dye over wide $\mathrm{pH}(7-11)$ and temperature $\left(25-40^{\circ} \mathrm{C}\right)$ ranges. The decolorization kinetics could be described by the Michaelis-Menten equation. The $K_{m}$ and $V_{\max }$ were found to be $443.3 \mathrm{mg} \mathrm{L}^{-1}$ and $166.7 \mathrm{mg} \mathrm{L}^{-1} \mathrm{~h}^{-1}$, respectively. FTIR analysis showed the decolorization is due to biodegradation. These results suggested that the $S$. xiamenensis G5-03 could be useful in the biological treatment of textile wastewater.

\section{REFERENCES}

AKSU, Z. Reactive dye bioaccumulation by Saccharomyces cerevisiae. Process Biochemistry, v. 38, n. 10, p. 1437-1444, 2003. http://doi.org/10.1016/S0032-9592(03)00034-7

APHA; AWWA; WEF. Standard Methods for the examination of water and wastewater. 22nd ed. Washington, 2012. 1496p.

CASTRO, K. C.; COSSOLIN, A. S.; REIS, H. C. O.; MORAIS, E. B. Biosorption of anionic textile dyes from aqueous solution by yeast slurry from brewery. Brazilian Archives of Biology and Technology, v. 60, p. 1-13, 2017. https://dx.doi.org/10.1590/1678-43242017160101

CHANG, J. S.; CHOU, C.; LIN, Y. C.; LIN, P. J.; HO, J. Y.; HU, T. L. Kinetic characteristics of bacterial azo-dye decolorization by Pseudomonas luteola. Water research, v. 35, n. 12, p. 2841-50, 2001. https://dx.doi.org/10.1016/S0043-1354(00)00581-9

GUADIE, A.; GESSESSE, A.; XIA, S. Halomonas sp. strain A55, a novel dye decolorizing bacterium from dye-uncontaminated Rift Valley Soda lake. Chemosphere, v. 206, p. 5969, 2018. https://dx.doi.org/10.1016/j.chemosphere.2018.04.134

HOLKAR, C. R.; PANDIT, A. B.; PINJARI, D. V. Kinetics of biological decolorisation of anthraquinone based Reactive Blue 19 using an isolated strain of Enterobacter sp.F NCIM 5545. Bioresource Technology, v. 173, p. 342-351, 2014. https://dx.doi.org/10.1016/j.biortech.2014.09.108

HSUEH, C.; YOU, L. P.; LI, J. Y.; CHEN, C. T.; WU, C. C.; CHEN, B. Y. Feasibility study of reduction of nitroaromatic compounds using indigenous azo dye-decolorizers. Journal of the Taiwan Institute of Chemical Engineers, v. 64, p. 180-188, 2016. https://dx.doi.org/10.1016/j.jtice.2016.04.015

HUSSAIN, S.; MAQBOOL, Z.; ALI, S.; YASMEEN, T.; IMRAN, M.; MAHMOOD, F.; ABBAS, F. Biodecolorization of Reactive Black-5 by a metal and salt tolerant bacterial strain Pseudomonas sp. RA20 isolated from Paharang drain effluents in Pakistan. Ecotoxicology and environmental safety, v. 98, p. 331-338, 2013. https://dx.doi.org/10.1016/j.ecoenv.2013.09.018

KHAN, Z.; JAIN, K.; SONI, A.; MADAMWAR, D. Microaerophilic degradation of sulphonated azo dye - Reactive Red 195 by bacterial consortium AR1 through cometabolism. International Biodeterioration and Biodegradation, v. 94, p. 167-175, 2014. https://dx.doi.org/10.1016/j.ibiod.2014.07.002 
KURADE, M. B.; WAGHMODE, T. R.; KHANDARE, R. V.; JEON, B. H.; GOVINDWAR, S. P. Biodegradation and detoxification of textile dye Disperse Red 54 by Brevibacillus laterosporus and determination of its metabolic fate. Journal of Bioscience and $\begin{array}{lllllll}\text { Bioengineering, } & \text { v. } 121, \quad \text { n. } 4, & \text { p. } & 442-449,\end{array}$ https://dx.doi.org/10.1016/j.jbiosc.2015.08.014

MENG, X.; LIU, G.; ZHOU, J.; FU, Q. S. Effects of redox mediators on azo dye decolorization by Shewanella algae under saline conditions. Bioresource technology, v. 151, p. 63-68, 2014. https://dx.doi.org/10.1016/j.biortech.2013.09.131

PÉREZ-CALDERÓN, J.; SANTOS, M. V.; ZARITZKY, N. Reactive RED 195 dye removal using chitosan coacervated particles as bio-sorbent: Analysis of kinetics, equilibrium and adsorption mechanisms. Journal of Environmental Chemical Engineering, v. 6, n. 5, p. 6749-6760, 2018. https://dx.doi.org/10.1016/j.jece.2018.10.039

SARATAlE, R. G.; SARATAlE, G. D.; CHANG, J. S.; GOVINDWAR, S. P. Bacterial decolorization and degradation of azo dyes: A review. Journal of the Taiwan Institute

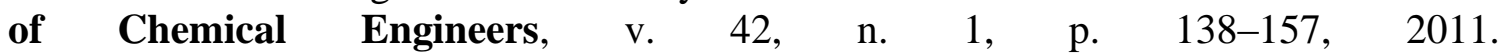
https://dx.doi.org/10.1016/j.jtice.2010.06.006

SHAH, P. D.; DAVE, S. R.; RAO, M. S. Enzymatic degradation of textile dye Reactive Orange 13 by newly isolated bacterial strain Alcaligenes faecalis PMS-1. International

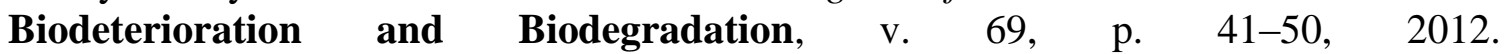
https://dx.doi.org/10.1016/j.ibiod.2012.01.002

TAN, L.; NING, S.; WANG, Y.; CAO, X. Aerobic decolorization of Acid Brilliant Scarlet GR by microbial community and the community dynamics during sequencing batch processes. World Journal of Microbiology and Biotechnology, v. 29, n. 10, p. 1763-1771, 2013. https://doi.org/10.1007/s11274-012-1249-1

VIKRANT, K.; GIRI, B. S.; RAZA, N.; ROY, K.; KIM, K. H.; RAI, B. N.; SINGH, R. S. Recent advancements in bioremediation of dye: Current status and challenges. $\begin{array}{llllll}\text { Bioresource Technology, } & \text { v. 253, p. 355-367, } 2018 .\end{array}$ https://dx.doi.org/10.1016/j.biortech.2018.01.029 